\title{
Assessment of Entrepreneurship Skills Development on Employment Generation Strategy in Tertiary Institutions in Lagos State
}

\author{
Waidi Adeniyi Akingbade \\ Department of Business Administration, Lagos State University, Lagos, Nigeria. \\ e-mail: akinwaidi@yahoo.com
}

DOI: 10.51865/EITC.2021.02.04

\begin{abstract}
The main purpose of this study is to examine the effects of entrepreneurship skills development on employment generation strategy in tertiary institutions in Lagos State. Descriptive survey research method was used to elicit information from the respondents. The population of study was 5000 students from eight tertiary institutions in the state that registered for ready set work programme organized by Lagos State government. The samples for the study were 370 using Yamane (1967) formula while, purposive and simple random sampling technique was used to select participants for the study and questionnaire administration was engaged as instrument to elicit information from the participants. Regression and ANOVA inferential statistical tools were adopted. Three tested hypotheses were consonant with the objectives of the study. The study revealed that employability skill had significant impact on job orientation; vocational skill enhanced job creation and life skill positively affect selfemployment. The study recommends the need for graduate of higher institutions to be adequately equipped with generic entrepreneurship skills in other to be employable, employer of labour, selfemployed and to compete in the global business environment to improve employment and reduce poverty.
\end{abstract}

Keywords: employability skill; vocational skill; life skill; ready set work; employment generation.

JEL Classification: E24.

\section{Introduction}

The significant roles played by entrepreneurship development towards attainment of economic growth and development cannot be underestimated and it has been recognized by countries all over the world as a way out of social economic problem (Lawal \& Williams, 2018; Kidane \& Harvey, 2009). The relevance of entrepreneurship in wealth creation, innovation, employment generation and economic growth has been highlighted by the global entrepreneurship monitor (Barba-Sanchez, \& Atienza-Sahuquillo, 2018). Furthermore, entrepreneurship programme has been developed in many countries of the world as a result of unemployment problems it solved through creation of small and medium businesses, provision of employment opportunities, income generation, uplifting of standard of living, and utilization of human, material and financial resources of a country in the right direction (Kidane \& Harvey, 2009). Entrepreneurship no doubt remains the gateway to sustainable wealth creation in Nigeria 
(Ogundele, 2000). Matanmi and Awodun (2005) noted that the growth and development of entrepreneurship skills in Nigeria is the way out of high level of unemployment which metamorphosed in to ravaging level of poverty. They concluded that Nigeria still remain in the doldrums because of the combination of ignorance, low capacity building and lack of encouragement of entrepreneurship.

Poverty is considered as one of the greatest problems facing many people across the globe and its eradication is tied to individual nation's economic growth, world peace and security (Dauda, 2017). Poverty is the outcome of unemployment and it affects all aspects of human living and it could only be fully understood by assessing everything that revolves around the living conditions of the working class and the people. Poverty can be assessed from the extent to which global capitalism has led to the inadequacy of income or disposable resources to the majority of the poor in many nations (Dauda, 2017). Major effects of poverty include poor nutritional status, lack of physical asset, inability to work, lower political, economic and social status and others are also used to assess human development and workers wellbeing. The increasing rate of poverty and unemployment in Nigeria has enable all tiers of government to resolved to entrepreneurship and small enterprise initiatives as an alternatives means of employment generations and possible way out of endemic poverty and unemployment problems in the country. Unemployment is considered as the proportion of those in the labour force who were actively looking for work but could not find work for at least 20hours during the reference period to the total currently active (labour force) population (NBS, 2015). Furthermore, Idris and Augustine (2018) noted that unemployment is involuntary idleness of a person willing to work at a prevailing rate of pay but unable to find job.

Meanwhile, the persistent increase in the unemployment rate in the country is alarming with the high unemployment rate of about 23.1 per cent, and underemployment of 16.6 per cent (National Bureau of Statistics, 2019). This condition is pathetic and has turned the country to the global poverty capital (World Poverty Circle, 2018). This has led to increasing rate of crimes and criminality, such as mass murders, insurgency, militancy, armed robbery, banditry, kidnappings and drug abuse, among others. Meanwhile, in order to reduce the poverty and unemployment problems in the country to the barest minimum, successive administrations in Nigeria have put about fourteen different social Intervention programmes in place but they were not targeted towards inculcating in graduates skills in entrepreneurship development and graduate employability to prepare them for the labour market to be employable and becomes employers of labour in the country.

Mass unemployment in the recent times has hindered government efforts for improved standard of living and wellbeing of average Nigerian. Successive governments in Nigeria have put in place different employment and social interventions strategies but majority of them have failed to yield desired results. This is because most of the programmes put in place were not directed to improve employability and self-employment to inculcate entrepreneurship skills development among graduate. Recent studies have revealed that graduate entrepreneurship skills development strategy is required to enhance graduate employability and to make them becomes employers of labour in the country. In order to achieve this, Lagos state government introduced ready set work (RSW) programme to promote graduate employability of major tertiary institutions in the state. The extent to which this programme has fulfilled this major aim is the main objective of this paper.

\section{Literature Review and Conceptual Framework}

\section{Ready Set Work (RSW)}

The RSW was put in place by the Lagos State Government to inculcate the skills of entrepreneurship and employability in the graduating students of all the tertiary institutions in 
Lagos State. Government aimed to turn the graduating students to employers of labour, job providers and not job seekers to reduce the problem of unemployment and poverty in the country. The trainees were all final year students who were at the end of their degree trajectory, while the trainers are volunteer's instructors from all sectors and different part of the country. All graduating students were invited to participate in the study (RSW, 2016).

RSW is an employability and entrepreneurship programme of Lagos State Ministry of Education designed to inculcate in the final year students' of tertiary institutions in Lagos State for immediate entry in to the labour market or work force as employees and employers of labour by equipping them with market-aligned knowledge, soft skills, business tools, and a belief reorientation to the world of work (RSW, 2016).

RSW is an initiative of the Lagos State Ministry of Education in partnership with a network of stakeholders including corporate Nigeria; Lagos State owned tertiary institutions and training partners. RSW is put in place to proffer solution to the lacunar in the skill of tertiary institutions graduate in order to reduce unemployment among graduate in the state. This is supported by thirteen weekends of intensive training in work based and entrepreneurial skills acquisition (RSW, 2016).

RSW was pilot tested in 2016 with 500 final year students from the following three tertiary institutions in Lagos State: Lagos State University, Ojo (LASU), Lagos State Polytechnic, Ikorodu (LASPOTECH) and Lagos State College of Health Technology, Yaba (LASCOHET). At the end of the programme 472 students graduated while 197 were successfully placed on internships and apprenticeship opportunities in the following organization Price water house coopers, Guaranty Trust Bank (GTB), First City Monument Bank (FCMB), Total Petroleum, Access Bank Plc, among others. In 2017, RSW trained 2000 final year students from 6 tertiary institutions in the state: LASU, LASPOTECH, LASCOHET, Adeniran Ogunsanya College of Education, Otto-Ijanikin (AOCOED), Michael Otedola College of Primary Education, Epe (MOCPED) and University of Lagos, Akoka (UNILAG). 1,000 of those students were successfully placed on internship and apprenticeship in various organizations. Further, RSW launched online academy to prepare and gave training in foundation courses for about 10,000 students in their penultimate year who show interest to participate in the full-fledged 13 Saturday weekends programme during their final year. RSW in 2018 trained 5,000 final year students and 20,000 students in their penultimate year drawn from 8 tertiary institutions in the state. In addition, there are internship/apprenticeship slots for 3000 students and those that are interested in being an entrepreneur have the opportunity to pitch their business ideas in and bid for seed funding. The 8 participated tertiary institutions are: LASU, LASPOTECH, LASCOHET, AOCOED, MOCPED, UNILAG, Yaba College of Technology, (YABATECH) Yaba and Federal College of Technical Education, (FCTE) Akoka (RSW, 2018).

Skills for Work: Education, vocational training, skill acquisition and lifelong learning are the backbone of employability, employment of workers, sustainability, enterprise, entrepreneurship development and contribute significantly to unemployment and poverty reduction (Kawar, 2011). Skills development is fundamental in stimulating a sustainable development process and can be instrumental to facilitating the transition from the informal to formal sector of the economy. The advantage of adequate investments in quality education and training firmly establishes that good education and training enhances people's capacities and creativity, opportunities, and satisfaction at work; empower people to develop their full capacities and seize employment and social opportunities, raise productivity of workers and of enterprises.

Employability: According to Yorke \& Knight (2003) as stated by Kawar (2011) employability is a series of achievements, skills, understandings and personal attributes that make graduates more likely to gain employment and be successful in their chosen occupations, carrier, which benefits themselves, the workforce, the community and the economy. While Harvey (2001), relate employability to the effort of student to secure, retain and develop in a job after 
graduation. It also improving student's features like skills, knowledge, attitudes, abilities and most importantly enhancing the student as a critical life-long learner (Weligamage, 2009; Harvey, 2001; Pollard, 1998).

Vocational Skills: These are skills that are acquired through learning, active study or practice that are useful in a work environment and for personal development. Some skills can be amassed over time to provide a more complete capability that a potential employer or an entrepreneur can use or is useful when working as a self-employed person providing a service. Some of these vocational skills can be acquired at training centre such as technical and vocational schools, apprenticeship centres, reading vocational books, attending structure courses that lasts for months among others (Akingbade \& Aberuagba, 2019; McGrath, 2010).

Vocational skills are occupations that people gain towards becoming knowledgeable in a specific trade or profession. Acquiring one or two vocational skills is a vital first step to entrepreneurship. Most successful business owners and entrepreneurs in Nigeria started by acquiring a vocational skill or training that are in high demand in the society (Ogundele, Akingbade \& Akinlabi, 2012). Vocational skills include writing, listening, oral presentation, organizing, coaching, being a team player, environmental scanning and technical know-how (Osuagwu, 2006).

Life Skills: Are basic skills acquired through learning and direct life experience that enable individuals and groups to effectively handle issues and problems commonly encountered in daily life. Unicef (2003) stated that life skills are also psychosocial abilities for adaptive and positive behaviour that enable individuals to deal effectively with the demands and challenges of everyday life. They are loosely grouped into three broad categories of skills: cognitive skills for analyzing and using information, personal skills for developing personal agency and managing oneself, and inter-personal skills for communicating and interacting effectively with others (Doyle, 2018). They include creativity, critical thinking, problem-solving, decisionmaking, the ability to communicate and collaborate, along with personal and social responsibility that contribute to good citizenship, all essential skills for success in the $21 \mathrm{st}$ century, both for healthy societies and for successful and employable individuals. These are skills that are useful in some one life, vary by culture, person's age and a mature adult is expected to have stronger life skills than a younger person (Doyle, 2018).

However, employers look for specific skills in the course of employing new workers like those that can manage challenges that come up at work with the aid of life skills. Employee with strong life skills are considered to displayed maturity and professionalism which are crucial to management and leadership positions. In this regard, Soukup (2020) identify forty-eight life skills required by everybody in our daily activities which include housekeeping skills like how to e.g. clean, cook, sewing, home repairs, unclog a toilet or sink, use kitchen appliances.

Technical skills required under life skills according to Soukup (2020) involved how to use the following; calendar \& schedule, write, public speaking, effective communication, technology, back up files, protect passwords, conduct of research, keep yourself safe, emergency preparedness, basic first aid, survive through other means without electricity, map reading, car repair, fix a flat tire, write a curriculum vitae $\&$ cover letter. It also include money management skills such as budget preparation, debt prevention and settlement, purchasing, bank account balancing, uses coupons, financial records documentation, money management and investment, tax professional selection, effective negotiation, tip calculation (Soukup, 2020).

Soukup (2020) argued that self-awareness skills encompasses the following; understanding why you are calling, objectives and mission, itemize your needs in hierarchical order, knowing your values, focus, possessed sense of humour, rule and civics right. He further stated that giving your partners attention, showing love and respect, accepting thanks and complaints, emotional intelligence, appreciating through text messages are classify as relationship skills. Wellness \& mental health skills, according to him are deep thinking, way-out of challenges, synthesizing, 
doing exercise \& nutrition, self-care like enough resting \& cleanness, happiness, speaking and relating with people, resolving problem, information technology, among others.

Employability Skills: Are core competencies that are useful in many professions and provide an avenue for the development of skills needed by people that are working and involve some interaction with machines, but help individuals maintain positive social relationships and contribute to the work environment (Kearns, 2001).

Employability skills include communication and interpersonal skills, problem solving skills, using your initiative and being self-motivated, working under pressure and to deadlines, organisational skills, team working, ability to learn and adapt, using mathematical ideas and techniques, using technology, valuing diversity and difference and negotiation skills (Kearns, 2001; Caleb \& Udofia, 2013).

Tertiary institutions graduates are supposed to be exposed to and understand the following employability skills to earn them job and valuable in the labour market, these are core, key, generic, soft and employability skill that graduate must possess to make them employable which include communication, application of numbers, team working, problem solving, learning to learn, among others (Kawar, 2011). Kwork (2003) and Becker (1964) argued that as part of human capital, general employability skills are further stressed as major factor and fundamental to aggregate economic growth and development and improved labour market outcomes for individuals. While, Lowe and Schellenberg (2001) as reported by (kwork, 2003) alluded to the fact that, at an individual level, the acquisition of general employability skills contribute to personal development, through improved participation in society and professionally, in relation to favourable labour market outcomes and earnings, for example, individuals invest time and money in order to become more skilled. In the same vain, Weligamage (2009) noted that tertiary institutions a citadel of learning and human capital development centre play significant roles in training graduate to acquire employability and their responsibility to identify how they can enhance skills of their future employees. The graduates of tertiary institutions are expected to be more employable, develop within the work, and cope with changes in dynamic, volatile and turbulent Nigeria business environment having acquired the above stated generic or employability skills.

Unemployment rate: This is the number of unemployed divided by the total labour force. The following different types of unemployment as identified by (Idris \& Augustine, 2018 \& Oguji, Okafor \& Nzem, 2004) ranges from Structural unemployment a situation when economic changes are massive, extensive and deep rooted amounting to transformation of an economic structure; unemployment occur due to mismatch of supply of demand for labour. Frictional unemployment arises as a result of labour immobility which leads him out of work for temporary period. Cyclical unemployment is due to cyclical fluctuation in the economy and during the down swing from the business cycle. While, Seasonal unemployment occurs due to seasonal variations nature of an industry. Technological unemployment arises from advancement in technology such as invention of a new machine or an innovation that may reduce the demand for labour. Residual unemployment takes place due to physical or mental disability. Disguised unemployment occurs when a person takes up a less suitable job for want of a better one. Mass or open unemployment is a situation where a significant number of labour forces are jobless. Youth or graduate unemployment is when many youth or graduate are without jobs.

Job Orientation: Is the process of welcoming new employees and giving them important information they need to take off their job such as rules and regulations about the place of work, facilities, pay, benefits, dress code, culture, work areas, co-workers, important information about the workplace, equipment, and the employees are giving the opportunities to ask questions about the company (Spacey, 2018; Rabha, 2020). Job orientation is a movement to new place of work in an unfamiliar environment and conforms to new surroundings, settle with 
new employee, adjust to a new culture, fit in to the new system, explain to the new workers what their new jobs entails and the objectives of the organization. Spacey (2018) identify the following twelve common organization elements to be expect at job orientation; mission and vision, culture, introductions, social events, structure, business overview, administration, benefits, policy, training, tours, and scare tactics. Consequently, sociological model summarized forms of experiencing work in to three as job, a carrier and a calling (Bellah, Madsen, Sullivan, Swindler, \& Tipton., 1985; and Pitacho, Palma, \& Correia, 2019).); while Wrzesniewski (2003) concluded that job orientation shows different incentives and relationships with work.

Self-Employed: This is a person who works for himself by earns a living and not as a worker in any organization or with another employers who pays them a regular salary or wages. Selfemployed individual operates his own business which can be run in different ways like sole trader or businesses that is own and manage by one owner only; partner in a partnership there portion in the running of a business ownership is on the basis of profits and losses; one owner limited liability companies (LLCs) operates the business like sole trader but has limited protection, while multiple owners LLCs operates there business in form of partners in partnership. Self-employed as noted by Dollarhide (2020) refers to anybody who earns their living from any independent pursuit of economic activity as opposed to earning a living working for a company, an individual or an employer. (Murray, 2020)

Job Creation: This is the other side of unemployment and the intention is that jobs are created in response to some sort of event. Meanwhile, increase in demand for organization products or services necessitate engagement of more skill employees that can execute the job at cheapest cost of production (Mclnnes, 2012). While, ILO (2017) and OECD (2014) submitted that creating more and better quality jobs are fundamental to economic growth, poverty reduction and increasing social cohesion. They further noted that stable macroeconomic framework in connection with structural policies that enhance innovation, skills and business development are necessary for job provision at national level.

\section{Theoretical framework}

Educational Theory serve as the basis of this study and it is concerned with general level of education in the society. Its proponents contended that education tend to broaden peoples' outlook. It equips people with needed skills to look at the world around them in a more organized and coordinated fashion. This will make them to perform better in entrepreneurial role (Aluko, 1983; Bowen and Histrich, 1986 \& Singh, 1986). Akeredolu-Ale (1975) found that more entrepreneurs had lower levels of education but could not establish any direct association between their level of formal education and degree of success achieved. Bowen \& Histrich (1986) \& Singh (1986) reported that the general conclusion that entrepreneurs are less well educated than the general population was not supported by their studies. Aluko (1983) argued that new breeds of highly educated entrepreneurs were emerging in Nigeria. While, Ogundele (2000) found that the performance of some entrepreneurs in his studied groups was aided by better education which many of them had. The broaden outlook through the educational process could aid in accurate perception of opportunities, and therefore affect entrepreneurial emergence, behaviour and performance.

\section{Research Methodology}

This study adopted survey research design in view of the descriptive nature of the research. Survey is one of the most common research strategies in business and management and used to answer questions of what, where, who, how much and how (Saunders, Lewis \& Thornhill, 2014). Therefore, a survey of final year students of purposeful selected 8 tertiary institutions in the state were undertaken in 2018 which focus on assessment of entrepreneurship skills 
development on employment generation strategy in selected tertiary institutions in Lagos state which participated in RSW. This is to be accomplished through a strategic intervention of thirteen weekends Saturday's of intensive face to face training in work based and entrepreneurship skills acquisition in 3 designated centres. The trainees were all final year students who were at the end of their degree trajectory, while the trainers are volunteer's instructors from all sectors and different part of the country. All graduating students were invited to participate in the study. Data were gathered through survey of undergraduates that participated in RSW. Global Report of Global Entrepreneurship Monitor (GEM, 2015) has revealed that fresh graduates usually demonstrate the tendency in the direction of starting a business; hence the questionnaires were administered on the final year students that enrolled in RSW.

\section{Population, sample size and sampling technique}

The population of this study was 5000 which covered all the registered final year students from the tertiary institutions that participated in $2018 \mathrm{RSW}$ programme at the following three designated centres across the state: LASU, Ojo; LASPOTECH, Ikorodu and UNILAG, Akoka. The eight participated tertiary institutions are; LASU,Ojo; LASPOTECH, Ikorodu; LASCOHET, Yaba; AOCOED, Otto-Ijanikin; MOCPED, Epe; UNILAG, Akoka; YABATECH, Yaba; and FCTE, Akoka. The total samples for the study were 370 using the Yamane (1967) formula.

The survey instrument used for collecting primary data was a self-administered questionnaire which was mainly designed to elicit information from participating students and consisted of two broad sections. The first section pertained to background information. The second section assessed the generic skill and job orientation, vocational skill and job creation and life skill and self-employment acquired by the participating respondents in the course of the 13 Saturdays RSW programme. Respondents were requested to indicate how significant was skills in employment generation using a 1 to 5 point likert scale ratings from Strongly Disagree $=1$ to Strongly Agree $=5$. The instrument was adapted from an abridged form of Weligamage (2009) and Harvey (2002) research instruments.

The Cronbach reliability coefficient test result of the instrument was of 0.89 above the benchmark of 0.70 showing high level of reliability. On the validity of the instrument, congruent and logical validity were adopted. While the former was carried out through variable measures from extant literature, the later was designed through the administration of a set of questionnaire draft to few selected experts in entrepreneurship studies who validated the draft instrument and necessary corrections were made before the administration. The generated data through the questionnaire were analysed by the means of descriptive and inferential statistics of regression and ANOVA to test the hypotheses of the study.

\section{Model Specification}

Where:

$$
\begin{aligned}
& \mathrm{JO}=\beta_{0}+\beta_{1} \mathrm{ES}+\mu \\
& \mathrm{JC}=\beta_{0}+\beta_{1} \mathrm{VS}+\mu \\
& \mathrm{SE}=\beta_{0}+\beta_{1} \mathrm{LS}+\mu
\end{aligned}
$$

$\mathrm{JO}=\mathrm{Job}$ Orientation;

$\mathrm{JC}=$ Job Creation;

$\mathrm{SE}=$ Self Employment;

ES = Employability Skill;

VS = Vocational Skill;

LS = Life Skill;

$\beta_{0}=$ Constant;

$\beta_{1}=$ Coefficient of the Variable; 
$\mu=$ Error Term.

\section{Justification of the Variables}

Job Orientation (JO) - this is the movement to new place of work in an unfamiliar environment and conforms to new surroundings, settle with new employee, adjust to a new culture, fit in to the new system, explain to the new workers what their new jobs entails and the objectives of the organization.

Job Creation (JC) - this is the intention of establishing job opportunities in the economy.

Self-Employment (SE) - this is a situation whereby an individual works for himself by earning a living and not as a worker in any organization.

Employability Skill (ES) - this is the core competency that is useful in many professions and provides an avenue for the development of skills needed by people that are working.

Vocational Skill (VS) - this is the skill that is acquired through learning, active study or practice that will be useful in a work environment and for personal development.

Life Skill (LS) - this is the skill that is acquired through learning and direct life experience that enable individuals and groups to effectively handle issues and problems commonly encountered in daily life.

\section{Research Findings}

In an attempt to justify the effects of entrepreneurship skills development on employment generation, data generated were analysed using descriptive and inferential of regression analysis. Tables 1-3 presents the results of three tested hypotheses to assessed entrepreneurship skill development as employment generation strategy in tertiary institutions in Lagos State.

To justify the impacts of employability skill on job orientation an inferential statistics of regression was employed.

$\mathbf{H}_{\mathbf{O} 1}$ : Employability skill does not have significant impact on job orientation in Lagos State.

Table 1. Regression Analysis

$\begin{array}{rrrr}\mathrm{r}^{2} & 0.317 & \mathrm{n} & 290 \\ \mathrm{r} & 0.563 & \mathrm{k} & 1\end{array}$

Std. Error 0.572

Dep. Var. Job Orientation

\begin{tabular}{rrrrrr}
\multicolumn{1}{l}{ ANOVA table } \\
\hline Source & SS & $d f$ & $M S$ & $F$ & $p$-value \\
\hline Regression & 43.5767 & 1 & 43.5767 & 133.38 & 0.000 \\
Residual & 94.0923 & 288 & 0.3267 & & \\
\hline Total & 137.6690 & 289 & & & \\
\hline
\end{tabular}

\begin{tabular}{rrrrrrr}
\multicolumn{1}{l}{ Regression output } & \multicolumn{3}{c}{ confidence interval } \\
\hline & & & $t(d f=$ & \multicolumn{3}{c}{$95 \%$} \\
variables & Coefficients & std. error & $288)$ & p-value & lower & $95 \%$ upper \\
\hline Intercept & 0.2430 & 0.2017 & 1.205 & 0.000 & -0.1539 & 0.6399 \\
Employability Skill & 0.8614 & 0.0746 & 11.549 & 0.000 & 0.7146 & 1.0082 \\
\hline
\end{tabular}


Interpretation: The regression analysis output shows that there is a positive relationship between employability skill and job orientation in Lagos state $(\mathrm{r}=0.563)$. The coefficient of determination $\left(\mathrm{R}^{2}=0.317\right)$ shows that $31.7 \%$ of the variance in job orientation is explained by employability skill. This result is statistically significant because the p-value for the result $(0.000)$ is less than the level of significant $(0.05)$ used for the study. The ANOVA result indicates that the overall regression model developed predicts job orientation significantly because the calculated $\mathrm{F}$ ratio of 133.38 is greater than the tabulated $\mathrm{F}$ ratio value of $3.00\left(\mathrm{~F}_{1,288}\right.$ $=3.00$ ) and the generated p-value is less than 0.05 which is statistically significant at $95 \%$ confidence interval.

Regression model:

$$
\begin{gathered}
\mathrm{JO}=\beta_{0}+\beta_{1} \mathrm{ES}+\mu \\
\mathrm{JO}=0.243+0.861 \mathrm{ES}+\mu
\end{gathered}
$$

Decision: The results of regression coefficients reveals that employability skill (ES) contributes statistically significantly to the model $(\beta=0.861, \mathrm{t}=11.549, \mathrm{p}=0.000)$ and can be used to predict job orientation (JO). For every additional unit of employability skill (ES), job orientation (JO) is expected to increase by an average of 0.861 units.

On the strength of this result $\left(\mathrm{R}^{2}=0.317, \mathrm{~F}_{1,288}=133.38, \mathrm{p}<0.05\right)$, this study rejects the null hypothesis and accept the alterative hypothesis. Therefore, it can be concluded that employability skill (ES) has significant impact on job orientation (JO) in Lagos state.

$\mathbf{H}_{\mathbf{O} 2}$ : Vocational skill does not influence job creation in Lagos state.

Table 2. Regression Analysis

$\begin{array}{rrrr}\mathrm{r}^{2} & 0.240 & \mathrm{n} & 290 \\ \mathrm{r} & 0.490 & \mathrm{k} & 1\end{array}$

Std. Error $0.461 \quad$ Dep. Var. Job Creation

\begin{tabular}{|c|c|c|c|c|c|c|}
\hline Regression output & & & & & confider & e interval \\
\hline variables & coefficients & std. error & $\begin{array}{r}t(d f= \\
288)\end{array}$ & $p$-value & $\begin{array}{r}95 \% \\
\text { lower }\end{array}$ & 95\% upper \\
\hline Intercept & 1.5714 & 0.1239 & 12.680 & 0.000 & 1.3275 & 1.8154 \\
\hline Vocational Skill & 0.4260 & 0.0447 & 9.532 & 0.000 & 0.3380 & 0.5139 \\
\hline
\end{tabular}

\begin{tabular}{rrrrrrr}
\multicolumn{1}{l}{ ANOVA table } & \multicolumn{1}{c}{ SS } & $d f$ & $M S$ & $F$ & $p$-value \\
\hline Regression & 19.3478 & 1 & 19.3478 & 90.85 & 0.000 \\
Residual & 61.3332 & 288 & 0.2130 & & \\
\hline Total & 80.6810 & 289 & & & \\
\hline
\end{tabular}

Interpretation: The regression analysis output shows that there is a positive relationship between vocational skill and job creation in Lagos state $(r=0.49)$. The coefficient of determination $\left(\mathrm{R}^{2}=0.24\right)$ shows that $24 \%$ of the variance in job creation is accounted for by vocational skill. This result is statistically significant because the p-value for the result $(0.000)$ is less than the level of significant (0.05) used for the study. The ANOVA result indicates that the overall regression model developed predicts job creation significantly because the calculated $\mathrm{F}$ ratio of 90.85 is greater than the tabulated $\mathrm{F}$ ratio value of $3.00\left(\mathrm{~F}_{1,288}=3.00\right)$ and $\mathrm{p}$-value is less than 0.05 which is statistically significant at $95 \%$ confidence interval.

Regression model:

$$
\mathrm{JC}=\beta_{0}+\beta_{1} \mathrm{VS}+\mu
$$




$$
\mathrm{JC}=1.5714+0.4260 \mathrm{VS}+\mu
$$

Decision: The results of regression coefficients reveals that vocational skill (VS) contributes statistically significantly to the model $(\beta=0.4260, t=9.532, p<0.05)$ and can be used to predict job creation (JC). For every additional unit of vocational skill (VS), job creation (JC) is expected to increase by an average of 0.8614 units.

The strength of this study result show that $\left(\mathrm{R}^{2}=0.24, \mathrm{~F}_{1,288}=90.85, \mathrm{p}<0.05\right)$, therefore the null hypothesis was rejected and alternative hypothesis was accepted. This indicates that vocational skill (VS) has significant influence on job creation (JC) in Lagos state.

$\mathbf{H}_{\mathbf{O} 3}$ : Life skill does not significantly affect self-employment in Lagos state.

Table 3. Regression Analysis

$$
\begin{array}{rrrl}
\mathrm{r}^{2} & 0.269 & \mathrm{n} & 290 \\
\mathrm{r} & 0.519 & \mathrm{k} & 1 \\
\text { Std. Error } & 0.456 & \text { Dep. Var. } & \text { Self-employment }
\end{array}
$$

\begin{tabular}{|c|c|c|c|c|c|}
\hline Source & $S S$ & $d f$ & $M S$ & $F$ & $p$-value \\
\hline Regression & 22.0668 & 1 & 22.0668 & 106.05 & 0.000 \\
\hline Residual & 59.9289 & 288 & 0.2081 & & \\
\hline Total & 81.9957 & 289 & & & \\
\hline
\end{tabular}

\begin{tabular}{rrrrrrr}
\multicolumn{1}{l}{ Regression output } & \multicolumn{3}{c}{ confidence interval } \\
\hline & & & $t(d f=$ & \multicolumn{3}{c}{$95 \%$} \\
variables & coefficients & std. error & $288)$ & p-value & lower & $95 \%$ upper \\
\hline Intercept & 1.3494 & 0.1321 & 10.218 & 0.000 & 1.0895 & 1.6093 \\
Life Skill & 0.5038 & 0.0489 & 10.298 & 0.000 & 0.4075 & 0.6001 \\
\hline
\end{tabular}

Interpretation: The regression analysis output shows that there is a positive relationship between life skill and self-employment in Lagos state $(\mathrm{r}=0.49)$. The coefficient of determination $\left(\mathrm{R}^{2}=0.269\right)$ shows that $26.9 \%$ of the variance in self-employment is accounted for by life skill. This result is statistically significant because the p-value for the result $(0.000)$ is less than the level of significant (0.05) used for the study. The ANOVA result indicates that the overall regression model developed predicts self-employment significantly because the calculated $F$ ratio of 106.05 is greater than the tabulated $F$ ratio value of $3.00\left(F_{1,288}=3.00\right)$ and $\mathrm{p}$-value is less than 0.05 which is statistically significant at $95 \%$ confidence interval.

Regression model:

$$
\begin{gathered}
\mathrm{SE}=\beta_{0}+\beta_{1} \mathrm{LS}+\mu \\
\mathrm{SE}=1.3494+0.5038 \mathrm{LS}+\mu
\end{gathered}
$$

Decision: The results of regression coefficients reveals that life skill (LS) contributes statistically significantly to the model $(\beta=0.5038, \mathrm{t}=10.298, \mathrm{p}<0.05)$ and can be used to predict self-employment (SE). For every additional unit of life skill (LS), self-employment (SE) is expected to increase by an average of 0.426 units.

The result strength shows that $\left(\mathrm{R}^{2}=0.269, \mathrm{~F}_{1,288}=106.05, \mathrm{p}<0.05\right)$, therefore the null hypothesis was rejected and alternative hypothesis was accepted. This shows that life skill (LS) significantly affect self-employment (SE) in Lagos state. 


\section{Discussion}

The study assessed entrepreneurship skills development as employment generation strategy in tertiary institutions in Lagos State. The outcome from the result above was supported with the inferences made with respect to existing studies. Findings showed that employability skills has significant impact on job orientation in line with the findings of Kwork, (2003) \& Becker, (1964), that employability skills is instrumental to aggregate economic growth, development and improved labour market outcomes for individuals. Moreover, research outcomes of Lowe \& Schellenberg (2001), Kwork (2003) \& Spacey (2018) agreed that employability skills contribute to personal development, through improved participation in society and professionally, in relation to favourable labour market outcomes, earnings, welcoming employees and provide them with relevant information to start their job. Furthermore, the positive and significant relationship between vocational skills and job creation corroborates the findings of Ogundele et al, (2012) \& Mclnnes (2012) where a positive link was found between vocational skills and job creation. Ogundele et al, (2012) and Mclnnes (2012) remarked that most successful business owners and entrepreneurs in Nigeria started by acquiring a vocational skill or training that are in high demand in the society, while job creation is the opposite of unemployment and works are provided in response to some sort of activities. It also provides support for the findings of Akingbade, et al, 2019 \& McGrath, 2010 when they reported that some of these vocational skills can be acquired at training centre such as technical and vocational schools, apprenticeship centres, reading vocational books, attending structure courses that lasts for months among others. Furthermore, the statistically positive and significant relationship between life skills and self-employment are in agreement with the findings of Doyle (2018) and (Dollarhide, 2020), where life skills enhance self-employment. Life skills was grouped into three broad categories by Doyle (2018) as cognitive skills for analysing and using information, personal skills for developing personal agency and managing oneself, and inter-personal skills for communicating and interacting effectively with others. Consequently, Doyle (2018) and Dollarhide (2020) further noted that a mature adult is expected to have stronger life skills which enhance is employability than a younger person.

\section{Conclusions}

The objective of this study was the assessment of entrepreneurship skills development as employment generation strategy in tertiary institutions in Lagos State. It was specifically to determine whether employability skills have significant impact on job orientation, vocational skill influence job creation, life skill significantly affect self-employment. The findings revealed that employability skill have significant impact on job orientation, vocational skill on job creation, life skill significantly affect self-employment.

Therefore, the study recommended that current curriculum of RSW programme should be review to meet the current challenges of graduate employability and entrepreneurship development in graduate such as education system not teaching the right skills, excess government regulations, advance in technology leading to loss of certain types of jobs by inculcating generic skills in youth and graduate. Unemployed youth and RSW graduate should acquire and put in to practice the following entrepreneurship skills; employability skills, life skills, vocational and technical skills, to enhance their level job orientation, job creation, and self-employment. Major impediment faced by unemployed youth and small business owner in the course of operation is inadequate access to finance, therefore in order to achieve the objective of the programme Lagos State Government should make the loan available to unemployed youth and RSW graduates as well as ease access to different source of finance from financial institutions. Fundamental courses of unemployment in the country include security challenges, epileptic power supply, infrastructural decay, unfavourable tax regime, corruption, bad management practice, turbulent business environment, challenges of globalization among 
others should be given proper attention by government at all level for unemployed youth and RSW graduates to achieve the programme objective of self-employed and employers of labour in an enabling environment. RSW graduate and unemployed youth should take to the following fifteen key lessons identify by Deluca \& Hayes (2001): to start and run a successful business; start small, earn a few kobo, begin with an idea, think like a visionary, keep the faith, ready fire aim, profit or perish, be positive, continuously improve your business, believe in your people, never run out of money, attract new customers every day, be persistent, build a brand name and opportunity waits for no one. RSW programme should be embraced by the federal, states and local governments of the federation because the great number of challenges faced by the country can be overcome through development of innovation, skilful and entrepreneurship oriented graduate who have the skills and ability to think out of the box.

The contribution of the study to the body of knowledge is that unemployed youth and RSW graduate should acquire and put in to practice the following entrepreneurship skills constructs; employability skill, life skill, vocational and technical skill, are instrumental to job orientation, job creation, and self-employment of graduate and unemployed youth. However, the limitation of the study is that it was limited to only tertiary institutions in Lagos State, Nigeria. The study suggested for further studies to cover all the tertiary institutions in the Country.

\section{References}

1. Akeredolu-Ale, E.O. (1975). The Underdevelopment of Indigenous Entrepreneurship in Nigeria. Ibadan: Ibadan University Press.

2. Akingbade, W.A., \& Aberuagba, O.T. (2019). Entrepreneurial Education for Youth Business Skills Development in Lagos State. LASU Journal of Management Sciences, 5 (1), 1-15.

3. Aluko, S. (1983). Research in entrepreneurial development in Nigeria in U. Udo-Aka, (Eds) Management Education for National Development. Lagos: Centre for Management Development.

4. Barba-Sanchez, V., \& Atienza-Sahuquillo, C. (2018). Entrepreneurial Intention among Engineering Students: The role of Entrepreneurial Education. European Research on Management and Business Economics, 24 (1), 53-61. doi: 10.1016/j.iedeen.2017.04.001

5. Becker, G.S. (1964). Human Capital: A Theoretical and Empirical Analysis, New York: Columbia University Press.

6. Bellah, R.N., Madsen, R.., Sullivan, W.M., Swindler. A., and Tipton., S.M. (1985). Habits of the heart. New York: harper \& row

7. Bowen, D.D., \& Histrich, R.D. (1986). The Female Entrepreneur: a career development perspective. Academy of Management Review, 11 (2), 393-407.

8. Caleb, E. C., \& Udofia, A.E. (2013). Generic Skills and the Employability of Electrical Installation Students in Technical Colleges of Akwa Ibom State, Nigeria. Journal of Research \& Method in Education 1, (2) 59-67.

9. Dauda, Y.A. (2017). Managing Global Poverty Challenge: Human Development and Workers wellbeing Perspectives. Ibadan: Taqwa Equity Press.

10. Deluca, F., \& Hayes. J.P. (2001). Start Small, Finish Big: Fifteen Key Lessons to Start and run your own Successful Business. New York: Warner Books.

11. Dollarhide, M. E. (2020). Self-Employment. Retrieved from www.investopedia.com/terms/s/selfemployed.asp

12. Doyle, A. (2018). The Balance BIZCATALYST $360^{\circ}$ Retrieved from https://www.bizcatalyst360.com/about/

13. Fukunishi, T. (2017). Skills development for youth in Africa. IDE Research Bulletin.

14. Global Entrepreneurship Monitor (2015). GEM 2015 Reports USA, Babson.

15. Harvey, L. (2001). Defining and measuring employability quality in higher education. 7 (2).

16. ILO (2017). Job creation and local economic development, Retrieved from www.ilo.org/global/lang$\underline{\text { en }}$

17. Kawar, W. (2011). Skills development for job creation, economic growth and poverty reduction. Paper presented at Doha, Qatar Forum on Decent work and poverty reduction. 25-26, October. 
18. Kearns, P. (2001). Generic Skills for the New Economy. Australia: National centre for vocational education and research.

19. Kidane, A., \& Harvey, B. H. (2009). Profile of Entrepreneurs: Employing stepwise regression analysis to determine the factors that impact the success of entrepreneurs. Review Business Research, 55-65.

20. Kwok, M. (2003). Research fellow division of post-secondary studies st. Paul's college, the university of manitoba draft - for comments only.

21. Lawal, A.A., \& Williams, M.B. (2018). Entrepreneurship education, entrepreneurial intentions and entrepreneurship success: Evidence from Nigerian Business and Engineering students. Proceeding of British Academy of Management $32^{\text {nd }}$ Annual Conference at the University of Bristol, West East of England, United Kingdom.

22. Matanmi, S. \& Awodun, M. (2005). An assessment of competitive strategies and growth patterns of new enterprises in Nigeria using the developing economy model. Lagos organization review, 1 (1) June-August, 26-32.

23. McGrath, S.J. (2010). Basic Managerial Skill for all. New Delhi: PHI Learning Private Limited

24. Mclnnes, J. (2012). What is job creation? Retrieved from www.quora.com/what-is-job-creation

25. National Bureau of Statistics. (2019).

26. OECD. (2014). Job Creation and Local Economic Development, OECD Publishing. doi: $10.1787 / 9789264215009$-en

27. Oguji, C.O.N., Okafor, J.N., \& Nzewi, A.S. (2004). The Comprehensive Basic Economics. Onisha: Joanee Educational Publishers Limited.

28. Ogundele, O.J.K. (2000). Determinants of Entrepreneur emergence behavior and performance in Nigeria, Ph.D thesis, University of Lagos, Nigeria.

29. Ogundele, O.J.K., Akingbade, W.A., \& Akinlabi, H.B. (2012). Entrepreneurship Training and Education as strategic tools for Poverty Alleviation in Nigeria. American International Journal of Contemporary Research, 2 (1), 148-156.

30. Osuagwu, L. (2006). Small Business and Entrepreneurship Management. Lagos: Grey resources Limited.

31. Pitacho, L.A., Palma, P., \& Correia, P. (2019). Work orientation: Dimensionality and internal model. Analise Psicologica, 37 (4), 479-491. Doi:10.14417/ap.1667

32. Proshare. (2015). Nigeria's Premier Financial, Business and Economic Information Hub, Lagos.

33. Rabha, M. (2020). Workplace orientation: What does it mean and its purpose?. Vantage circle HR blog

34. Ready Set Work (2016). RSW Lagos State Government Initiative. Retrieved from https://readysetwork.com.ng/programme-details/

35. Ready Set Work (2017). RSW Lagos State Government Initiative. Retrieved from https://readysetwork.com.ng/programme-details/

36. Ready Set Work (2018). RSW Lagos State Government Initiative. Retrieved from https://readysetwork.com.ng/programme-details/

37. Saunders, M., Lewis, R., \& Thornhill, A. (2014). Research methods for business students $\left(6^{\text {th }} \mathrm{ed}\right)$. UK: Pearson Education Limited.

38. Singh, R.N. (1986). Developing Entrepreneurship for Economic Growth. New Delhi: Vikas Publishing House.

39. Spacey, J. (2018). Twelve things to expect at job orientation. Retrieved from www.simplicable.co

40. Weligamage. (2014). Graduates' employability skills: Evidence from literature review. Enhancing employment through quality assurance.

41. World Poverty Clock. (2018). Poverty. Retrieved from http://www.worldpoverty.io/index.html

42. Wrzesniewski, A. (2003). Finding positive meaning at work. In K. Cameron.., J.E. Dutton., \& R.E. Quinn (Eds), Positive organizational scholarship. San Francisco: Beneth-Koehler Publishers. 